\title{
Canine visceral leishmaniasis: seroprevalence and risk factors in Cuiabá, Mato Grosso, Brazil
}

\author{
Leishmaniose visceral canina: soroprevalência e fatores de risco em Cuiabá, Mato Grosso, Brasil
}

\author{
Arleana do Bom Parto Ferreira de Almeida ${ }^{1,2 *}$; Valéria Régia Franco Sousa ${ }^{2}$; \\ Felipe Augusto Constantino Seabra da Cruz²; Magyda Arabia Araji Dahroug'; \\ Fabiano Borges Figueiredo ${ }^{3}$; Maria de Fátima Madeira ${ }^{4}$
}

\begin{abstract}
${ }^{1}$ Programa de Pós-graduaçáo em Pesquisa Clínica em Doenças Infecciosas, Instituto de Pesquisa Clínica Evandro Chagas - IPEC, Fundação Oswaldo Cruz - FIOCRUZ, Rio de Janeiro, RJ, Brasil

${ }^{2}$ Departamento de Clínica Médica Veterinária, Faculdade de Agronomia, Medicina Veterinária e Zootecnia, Universidade Federal de Mato Grosso - UFMT, Cuiabá, MT, Brasil

${ }^{3}$ Laboratório de Pesquisa Clínica em Dermatozoonoses de Animais Domésticos, Instituto de Pesquisa Clínica Evandro Chagas - IPEC, Fundação Oswaldo Cruz - FIOCRUZ, Rio de Janeiro, RJ, Brasil

${ }^{4}$ Laboratório de Vigilância em Leishmanioses, Instituto de Pesquisa Clínica Evandro Chagas - IPEC, Fundação Oswaldo Cruz - FIOCRUZ, Rio de Janeiro, RJ, Brasil
\end{abstract}

Received February 5, 2012

Accepted September 17, 2012

\begin{abstract}
In Brazil, canine visceral leishmaniasis (CVL) is endemic and the number of cases in humans and dogs has increased in the Midwest region. A transversal study was carried out in endemic areas from Cuiabá, State of Mato Grosso, to assess data on seroprevalence and risk factors associated to canine infection. Four hundred and thirty (430) dogs were randomly evaluated through indirect fluorescence antibody test (IFAT) considering variables related to the animals, the environment and the knowledge by owners on CVL aspects and control. From 430 dogs, 95 (22.1\%) were seroreagent for leishmaniasis and animals living in rural environments present risk 1.9 times higher for acquiring the disease than those in urban environments ( $\mathrm{p}=0.01$; OR 1.9). Factors related to animals' habits, such as free access to the street and guard function were considered indicators to predict infection by Leishmania sp. $(\mathrm{p}<0.05)$ by statistical univariate analysis. The presence of agricultural activities was also a fact that contributed for the insurgence of the infection $(\mathrm{p}=0.02$; OR 1.68). The results contributed to the knowledge on the aspects of CVL in Cuiabá and point to an urgent need to include educational and sanitary programs in the city, since the region presents favorable characteristics for spreading the infection of CVL as already observed in other Brazilian cities.
\end{abstract}

Keywords: Canine visceral leishmaniasis, dogs, risk factors, infection, Brazil.

\section{Resumo}

No Brasil, a leishmaniose visceral canina (CLV) é endêmica e, na região Centro-Oeste, o número de casos em humanos e cães tem aumentado. Um estudo transversal foi realizado em áreas endêmicas de Cuiabá (MT) com objetivo de avaliar dados sobre a soroprevalência e determinar os fatores de risco associados à infecçáo canina. Quatrocentos e trinta (430) cães foram aleatoriamente avaliados pelo teste de imunofluorescência indireta, considerando-se variáveis relacionadas aos animais, o ambiente e o conhecimento por parte dos proprietários sobre aspectos da CLV e seu controle. Dos 430 cáes, $95(22,1 \%)$ apresentaram-se soros reagentes para leishmaniose, e os animais que viviam em ambiente rural apresentaram risco 1,9 vezes maior de adquirir a infecção dos que aqueles em ambiente urbano $(\mathrm{p}=0,01$; OR 1,9). Fatores relacionados aos hábitos dos animais, tais como o livre acesso à rua e função de guarda, foram considerados indicadores para prever a infecção por Leishmania sp. $(\mathrm{p}<0,05)$ em análise estatística univariada. A presença de atividade agrícola foi também um fato que contribuiu para a ocorrência da infecção ( $\mathrm{p}=0,02 ; \mathrm{OR} 1,68)$. Os resultados contribuem para o conhecimento sobre os aspectos da CVL em Cuiabá e apontam para uma necessidade urgente de incluir açóes educativas e sanitárias na cidade, já que a região possui características favoráveis para a dispersão da doença como já observado em outras cidades.

Palavras-chave: Leishmaniose visceral canina, cães, fatores de risco, infecção, Brasil.

\footnotetext{
${ }^{*}$ Corresponding author: Arleana do Bom Parto Ferreira de Almeida

Hospital Veterinário da UFMT, Departamento de Clínica Médica Veterinária,

Universidade Federal de Mato Grosso - UFMT, Av. Fernando Correa da Costa,

2367, CEP 78060-900, Cuiabá, MT, Brasil

e-mail: arleferreira@gmail.com
} 


\section{Introduction}

In Brazil, the country with the highest register of cases of Canine Visceral Leishmaniasis (CVL) in the Americas (WHO, 2008), the disease is caused by Leishmania infantum (syn. Leishmania chagasi). In the transmission chain, wild and domestic dog reservoirs and two species of Phlebotominae: Lutzomyia longipalpis and L. cruzi (BRASIL, 2006) are be highlighted.

The chronic disease is the most severe clinical form of leishmaniasis and a serious problem for Brazilian public health, mainly due to the high prevalence and increased number of cases in humans and dogs in urban and suburban areas of large cities (ARIAS et al., 1996; MORENO et al., 2005; MARZOCHI et al., 2009). CVL urbanization has been associated to migration processes linked to the deterioration of social and economic conditions of the population (ANTONIALLI et al., 2007; HARHAY et al., 2011). Thus, an expansion of the disease to areas considered non-endemic has also been noticed in several Brazilian regions (DE PAULA et al., 2009; SOUZA et al., 2009). In the State of Mato Grosso (MT), in the Midwest region of country, the first report of human leishmaniasis dates from 1973 (BARUFFA; CURY, 1973); however, dissemination of the disease to many municipalities was observed in 1998, including Cuiabá, the capital city of the state (MESTRE; FONTES, 2007). In 2010, 313 cases of human visceral leishmaniasis (VL) were registered in Midwestern Brazil, with the State of Mato Grosso contributing with 54 cases (BRASIL, 2011).

Many risk factors to the occurrence of CVL have been determined, indicating possible interactions between the links that compose the epidemiological chain, such as vector, host, reservoirs and environment (GAVGANI et al., 2002; MURRAY et al., 2005; RANJAN et al., 2005; AMORA et al., 2006; RONDON et al., 2008). Thus, the knowledge of the disease distribution in endemic areas and possible associations between the disease and determinant factors may be helpful in control strategies (FREHSE et al., 2010). In this context, the domestic dog plays an important role, maintaining and spreading the disease. For this reason, factors that may be associated to the risk of infection to these animals must be well known (DANTAS-TORRES, 2009).

Thus, this research investigated the seroprevalence of CVL and the main risk factors associated to the infection of domestic dogs in the following neighborhoods: Barreiro Branco, Coxipó do Ouro, Osmar Cabral, Bela Vista and Jardim União, which are endemic areas in Cuiabá (MT), where cases of human disease have been reported.

\section{Materials and Methods}

\section{Study area}

Transversal study carried out in Cuiabá (MT), from July 2009 to December 2010. The municipality is located at the following coordinates: $15^{\circ} 35^{\prime} 56.10^{\prime \prime} \mathrm{S}$ and $56^{\circ} 05^{\prime} 41.62^{\prime} \mathrm{W}$, comprising an area of $3,538 \mathrm{~km}^{2}, 165 \mathrm{~m}$ above sea level, with predominant savanna vegetation. It presents hot and sub-humid tropical climate with $1750 \mathrm{~mm}$ average annual rainfall and maximum temperature around $43{ }^{\circ} \mathrm{C}$ during the warmest months and minimum temperature between $12{ }^{\circ} \mathrm{C}$ and $14^{\circ} \mathrm{C}$. Cuiabá has a population of 551,098 inhabitants; it is subdivided in four regions (IBGE, 2011). The evaluation of the dogs was performed in the neighborhoods located in the North region (Barreiro Branco and Coxipó do Ouro), which present rural characteristics, and in the neighborhoods located in the South, East and West regions: Osmar Cabral, Bela Vista and Jardim União, respectively, with urban environmental characteristics. Cases of human VL have already been described (data not published) in all the neighborhoods studied.

\section{Description of the animals}

Four hundred and thirty dogs of both genders and age equal or greater than six months were investigated. Canine sampling was defined considering disease prevalence of $8.4 \%$ (MESTRE; FONTES, 2007), with a significance level of $2 \%$ and $99 \%$ confidence interval based on the 2007 canine census. The survey was conducted through home visits, considering one residence for every five. After obtaining the owners' consent, the dogs were examined and clinically grouped according to Mancianti et al. (1988) for CVL in asymptomatic, oligosymptomatic and symptomatic. About $5 \mathrm{~mL}$ of blood were collected from each animal by cephalic or jugular puncture; the serum was then separated by centrifugation and kept at $-20{ }^{\circ} \mathrm{C}$ until serological test performance. This experiment was approved by the Ethics Committee on Animal Use of the 'Oswaldo Cruz' Foundation - protocol no LW-01/10.

\section{Serological test for diagnostics - Indirect Fluorescence Antibody Test-IFAT}

The serological analysis was carried out by IFAT technique using a commercial canine visceral leishmaniasis kit (BioManguinhos/FIOCRUZ, Rio de Janeiro, Brazil) following manufacturer's recommendations. The serum samples were diluted to the double from 1:40 to $1: 640$, samples with titer equal or superior to $1: 40$ were considered reagent, using control sera (positive and negative) included in the tests as reference.

\section{Studied variables}

Information was collected from the owners of the animals in order to describe the general and individual characteristics of the canine population and their environment, as well as to determine the risk factors associated to canine leishmaniasis infection in Cuiabá (MT). The following variables were considered: race (when it could be defined); gender (male, female); age ( $\leq 1$ year, 1 to 3 years, 3 to 6 years, $>6$ years, and indefinite); house role (guard, hunt, company); and animal habitat (limited to the interior of the house, peridomiciliar, free access to the street). The variables related to the household environment were the following: household close to agricultural activities; presence of other domestic animals (yes/no); presence of trees and animal breeding at the yard (yes/no); public garbage collection (yes/no); and knowledge on the occurrence of canine and human VL in the neighborhood (yes/no). 


\section{Statistical analysis}

The chi-square with Yate's correction and Fisher's exact test was used to test for associations between all of the parameters (Epi Info software, version 3.5.1, Center for Disease Control, Atlanta, USA). Differences were considered significant for $\mathrm{P}$-values $<0.05$. Any parameters statistically linked to seropositivity were used in a logistic regression model to assess risk factors associated with seropositivity results.

\section{Results}

From the 430 dogs studied, 95 were seropositive to the IFAT tests showing 22.1\% prevalence of CVL. Considering the origins of the animals, those from neighborhoods located in urban areas represented $18.8 \%$ of prevalence and in rural neighborhoods, $30.6 \%$ of prevalence, which was statistically significant $(\mathrm{p}=0.01)$ (Table 1).

The serological titers presented the following frequency: $1: 40$ $(\mathrm{n}=27 ; 28.4 \%), 1: 80(\mathrm{n}=32 ; 33.7 \%), 1: 160(\mathrm{n}=16 ; 16.8 \%)$, $1: 320(\mathrm{n}=6 ; 6.3 \%), 1: 640(\mathrm{n}=14 ; 14.7 \%)$.

From 95 seropositive dogs, 44 (46.3\%), 35 (36.8\%) and 16 $(16.8 \%)$ were clinically classified as asymptomatic, oligosymptomatic and symptomatic, respectively, with statistical significance between symptomatic and asymptomatic dogs $(\mathrm{p}=0.008)$. The most frequently clinical signs were related to the skin $(\mathrm{n}=37 ; 38.9 \%)$, such as dull fur, generalized alopecia, cutaneous ulcers and scaling followed by lymphadenomegaly $(n=34)$, loss of weight $(n=24)$, splenomegaly $(\mathrm{n}=18)$, vision disorders $(\mathrm{n}=14)$, onychogryphosis $(\mathrm{n}=13)$, apathy $(\mathrm{n}=12)$, muscular atrophy $(\mathrm{n}=4)$, and cachexia $(\mathrm{n}=2)$.

The association of CVL between gender, age or race was not statistically significant $(p>0.05)$. Six out of the 14 dogs were Pit Bulls, three were Pinschers and there was one of each of the following races: Brazilian Fila, Rottweiler, Poodle, Cocker Spaniel and Chow Chow. The fur type characteristic was also not significant for the occurrence of infection in the dogs; however, variables such as access to the street, guard role and staying most of the time outside the house, represented predictive characteristics for CVL in univariate analysis when compared with dogs kept inside or around the houses (Table 2).

Regarding to the origin of CVL seropositive dogs, 87 (91.6\%) were from Cuiabá, eight (8.4\%) from neighbor municipalities and one from another State (Mato Grosso do Sul). Seventy-five (78.9\%) were living with the family for over a year. The presence of other domestic animals and livestock in the rural area did not present association with seroreactivity for leishmaniasis ( $p>0.05)$; in contrast with the presence of crops around the household (uni and multivariate analysis), which was statistically significant (Table 3).

Knowledge about the CVL disease was reported by $69.3 \%$ ( $n=298)$ of dog owners. Interestingly, 75 (78.9\%) seropositive dogs were allocated in this group and this datum was considered significant in univariate analysis $(\mathrm{p}=0.02)$. Public garbage collection was reported in three neighborhoods located in urban areas and in one neighborhood located the in a rural environment (Coxipó do Ouro), but just as a sporadic activity. In the neighborhood where garbage collection service was not a usual practice, a significant statistical difference to this variable ( $\mathrm{p}=0.02$ and $\mathrm{OR} 4.53)$ was observed among the rural neighborhoods. Vaccines against CVL, as well as collars impregnated with insecticide, were not usual practices among dog owners for this disease control.

\section{Discussion}

Several epidemiological studies have been carried out on the importance of the dog as L. infantum reservoir in Brazil aiming to determine CVL prevalence in endemic and non-endemic areas (DANTAS-TORRES et al., 2006; SILVA et al., 2008; CRUZ et al., 2010; FREHSE et al., 2010). The present survey and serological analysis through IFAT detected the infection of Leishmania sp. in 95 (22.1\%) of dogs in Cuiabá, where CVL was recently installed. This rate of prevalence was higher than data reported in other studies accomplished in the same municipality (MESTRE; FONTES, 2007; ALMEIDA et al., 2009), and the reason may be that there were human cases of the disease reported in the same neighborhood. According to Marzochi et al. (2009),

Table 1. Serological prevalence and risk factors associated with Canine Visceral Leishmaniasis infection according to different neighborhoods in the city of Cuiabá State of Mato Grosso.

\begin{tabular}{|c|c|c|c|c|c|}
\hline \multirow{2}{*}{ Neighborhoods } & \multirow{2}{*}{$\begin{array}{c}\text { Dogs } \\
\text { (n) }\end{array}$} & \multicolumn{2}{|c|}{ IFAT positive dogs } & \multirow{2}{*}{ OR (CI 95\%) } & \multirow{2}{*}{ P-value* } \\
\hline & & $\mathbf{n}$ & $\%$ & & \\
\hline \multicolumn{6}{|l|}{ Rural Area } \\
\hline Barreiro Branco & 68 & 29 & 42.64 & $4.18(1.59-11.31)$ & $0.002^{\mathrm{b}}$ \\
\hline Coxipó do Ouro & 53 & 08 & 15.09 & & \\
\hline Total Rural Area & 121 & 37 & 30.6 & $1.91(1.15-3.17)$ & $0.01^{\mathrm{a}}$ \\
\hline \multicolumn{6}{|l|}{ Urban Area } \\
\hline Osmar Cabral & 107 & 13 & 12.14 & & \\
\hline Total Urban Area & 309 & 58 & 18.8 & & \\
\hline Total & 430 & 95 & 22.1 & & \\
\hline
\end{tabular}

${ }^{a}$ analysis between urban and rural areas; ${ }^{b}$ analysis between the neighborhoods Barreiro Branco and Coxipo do Ouro; ${ }^{c}$ analysis between the neighborhoods Jardim

União and Osmar Cabral; OR-Odds Ratio; *chi-square with Yate's correction and Fisher's exact test. 
Table 2. Univariate analyses for variables considered for the study of risk factors associated with Canine Visceral Leishmaniasis in 430 dogs from Cuiabá, State of Mato Grosso, Brazil.

\begin{tabular}{|c|c|c|c|c|c|c|}
\hline \multirow[t]{2}{*}{ Variables } & \multicolumn{2}{|c|}{$\begin{array}{l}\text { IFAT positive dogs } \\
(\mathrm{n}=95)\end{array}$} & \multicolumn{2}{|c|}{ IFAT negative $\operatorname{dogs}(n=335)$} & \multirow[t]{2}{*}{ OR (CI 95\%) } & \multirow[t]{2}{*}{ P-value* } \\
\hline & $\mathbf{n}$ & $\%$ & $\mathbf{n}$ & $\%$ & & \\
\hline \multicolumn{7}{|l|}{ Gender } \\
\hline Male & 56 & 58.9 & 175 & 52.2 & \multirow{2}{*}{$0.76(0.44-1.20)$} & \multirow{2}{*}{0.29} \\
\hline Female & 39 & 41.1 & 160 & 47.8 & & \\
\hline \multicolumn{7}{|l|}{ Age groups } \\
\hline$\leq 1$ & 11 & 11.6 & 52 & 15.5 & & \multirow{5}{*}{0.41} \\
\hline$\geq 1-3$ & 33 & 34.7 & 131 & 39.1 & & \\
\hline$\geq 3-6$ & 32 & 33.7 & 82 & 24.5 & & \\
\hline$\geq 6$ & 15 & 15.8 & 50 & 14.9 & & \\
\hline Indefinite age & 04 & 4.2 & 20 & 6.0 & & \\
\hline \multicolumn{7}{|l|}{ Breed } \\
\hline SRD & 81 & 85.3 & 268 & 80 & \multirow{2}{*}{$0.69(0.36-1.29)$} & \multirow{2}{*}{0.31} \\
\hline CRD & 14 & 14.7 & 67 & 20 & & \\
\hline \multicolumn{7}{|l|}{ Fur } \\
\hline Short & 79 & 83.2 & 275 & 82.1 & \multirow[t]{2}{*}{$0.92(0.48-1.67)$} & \multirow[t]{2}{*}{0.92} \\
\hline Long & 16 & 16.8 & 60 & 17.9 & & \\
\hline \multicolumn{7}{|l|}{ House role } \\
\hline Guard & 48 & 50.5 & 136 & 40.6 & \multirow{4}{*}{$1.78(1.05-3.01)$} & \multirow{4}{*}{$0.03^{\mathrm{a}}$} \\
\hline Company & 33 & 34.7 & 166 & 49.6 & & \\
\hline Both & 13 & 13.7 & 32 & 9.6 & & \\
\hline Hunt & 1 & 1.1 & 1 & 0.3 & & \\
\hline \multicolumn{7}{|l|}{ Dog habitat } \\
\hline Intradomestic & 1 & 1.1 & 5 & 1.5 & \multirow{3}{*}{$3.19(1.06-10.80)$} & \multirow{3}{*}{$0.03^{\mathrm{b}}$} \\
\hline Peridomiciliar & 90 & 94.7 & 289 & 86.3 & & \\
\hline Both & 4 & 4.2 & 41 & 12.2 & & \\
\hline
\end{tabular}

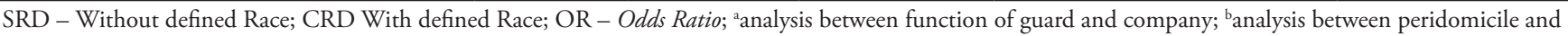
both; Intradomestic (limited to the interior of the house); *chi-square with Yate's correction and Fisher's exact test.

the canine disease tends to precede human cases, which are kept high in endemic areas. The presence of about $22 \%$ of leishmaniasis seropositive dogs is an important datum for the epidemiological surveillance of Cuiabá. Studies conducted in this city have already demonstrated the expansion of the canine disease even to areas even where no human cases have been reported (ALMEIDA et al., 2009).

Historically, VL originates from rural environments where epidemiological patterns facilitate the circulation of the agent. However, the urbanization of this disease is a fact observed in many Brazilian states, where control is seen as more complex (NASCIMENTO et al., 2008). The elevated prevalence determined in dogs from urban neighborhoods confirms the urbanization trend of VL in Cuiabá. However, it is important to highlight that rural neighborhoods hold the highest canine infection rate, representing a risk 1.9 times higher of acquiring the disease than in urban neighborhoods.

One of the visceral leishmaniasis control measures in Brazil is the elimination of seropositive dogs regardless of the clinical condition (BRASIL, 2006). In the epidemiological context, asymptomatic dogs are also important, representing a prevalence rate of $46.3 \%$ of seropositivity for CVL in the present study. As described in other Brazilian regions, the proportion of asymptomatic infected dogs has demonstrated significant prevalence when compared to clinically symptomatic dogs (DANTAS-TORRES et al., 2006).
Due to the importance of domestic dogs in the VL transmission cycle, risk factors for the occurrence of the canine infection have been widely analyzed (AMORA et al., 2006; RONDON et al., 2008). Variables such as gender, age, race and fur type evaluated in the present study were not associated to the risk of acquiring the infection. This was also observed in other endemic areas (RONDON et al., 2008; SANTOS et al., 2010), although some studies present conflicting results as to the gender, age and race variables (OLIVEIRA et al., 2010; SANTOS et al., 2010). In this matter, there are no diagnostic tests for CVL that present 100\% specificity and sensibility. The accuracy indices of these tests may vary as a function of the group studied and the criteria adopted to establish positive and negative gold standards (LUCEY; WEINA, 2008). Results of the IFAT - which is a serological method indicated by the Brazilian Ministry of Health (BRASIL, 2006) to confirm $\mathrm{CVL}$ - were used in this study. Despite the fact that, theoretically, any dog can develop the infection, a bimodal distribution of the canine infection has been described (DANTAS-TORRES et al., 2006), with peak of cases in dogs under three years of age and dogs between eight and ten years old, in accordance with observations of this study, where dogs under three years old were the most affected by the infection.

According to Santos et al. (2010), the local environment and risk factors may vary from one region to another, highlighting the 
Table 3. Univariate and multivariate analyses to detect risk factors associated with the IFAT positivity of Canine Visceral Leishmaniasis in dogs from Cuiabá, State of Mato Grosso, Brazil.

\begin{tabular}{|c|c|c|c|c|c|c|}
\hline \multirow{2}{*}{ Variables } & \multicolumn{2}{|c|}{ Dogs } & \multicolumn{2}{|c|}{ Univariate analysis* } & \multicolumn{2}{|c|}{ Multivariate analysis** } \\
\hline & Total & Positive (\%) & $P$ & OR (CI95\%) & $P$ & OR (CI95\%) \\
\hline \multicolumn{7}{|l|}{ Vegetation } \\
\hline Yes & 358 & $82(86.3)$ & 0.45 & 1.34 & & \\
\hline No & 72 & $13(13.7)$ & & $(0.77-2.82)$ & & \\
\hline \multicolumn{7}{|c|}{ Access to the street } \\
\hline Yes & 292 & $74(77.9)$ & 0.02 & 1.89 & & \\
\hline No & 138 & $21(22.1)$ & & $(1.10-3.32)$ & 0.78 & \\
\hline \multicolumn{7}{|c|}{ Domestic animals } \\
\hline Yes & 340 & $78(82.1)$ & 0.49 & 1.27 & & \\
\hline No & 90 & $17(17.9)$ & & $(0.75-2.46)$ & & \\
\hline \multicolumn{7}{|c|}{ Trees in the yard } \\
\hline Yes & 194 & $54(56.8)$ & 0.01 & 1.83 & 0.02 & 1.68 \\
\hline No & 236 & $41(43.2)$ & & $(1.13-2.98)$ & & $(1.05-2.69)$ \\
\hline \multicolumn{7}{|l|}{ Livestock } \\
\hline Yes & 163 & $40(42.1)$ & 0.40 & 1.25 & & \\
\hline No & 267 & $55(57.9)$ & & $(0.79-1.99)$ & & \\
\hline \multicolumn{7}{|c|}{ LVH neighborhood* } \\
\hline Yes & 47 & $14(14.7)$ & 0.24 & 1.58 & & \\
\hline No & 383 & $81(85.3)$ & & $(0.75-2.90)$ & & \\
\hline \multicolumn{7}{|c|}{ LVC neighborhood* } \\
\hline Yes & 56 & $22(23.2)$ & 0.002 & 2.66 & 0.004 & 2.43 \\
\hline No & 374 & $73(76.8)$ & & $(1.47-4.75)$ & & $(1.33-4.44)$ \\
\hline \multicolumn{7}{|l|}{ Vector* } \\
\hline Yes & 21 & $4(4.2)$ & 0.48 & 0.82 & & \\
\hline No & 409 & $91(95.8)$ & & $(0.17-2.07)$ & & \\
\hline \multicolumn{7}{|c|}{ Know disease* } \\
\hline Yes & 298 & 75 & 0.02 & 1.88 & 0.11 & \\
\hline No & 132 & 20 & & $(1.09-3.24)$ & & \\
\hline \multicolumn{7}{|c|}{ Insecticide use } \\
\hline Yes & 66 & $19(20)$ & 0.20 & 1.53 & 0.08 & \\
\hline No & 364 & $76(80)$ & & $(0.81-2.70)$ & & \\
\hline
\end{tabular}

*Knowledge reported by pet owner; OR - Odds Ratio; *chi-square with Yate's correction and Fisher's exact test; ${ }^{* *}$ logistic regression model.

mode of life of animals as one of the most important aspects to acquire CVL infection. In the present study, the statistical univariate analysis showed that guard role, free access to the street and living around the exterior of the house were factors associated to dog infection with risks 1.78, 1.89, 3.19 times higher for acquiring the disease, respectively. Such characteristics expose the animals to a bigger contact with the vector and, consequently, to the infection (AMORA et al., 2006; RONDON et al., 2008).

Environments degraded by disordered occupation have been described as another risk factor that facilitates the occurrence of CVL (MISSAWA; BORBA, 2009; MARZOCHI et al., 2009). The highest indexes of IFAT seropositive animals were observed in the neighborhoods located in rural environments and in the Jardim União neighborhood, which presented severe natural ecotope changes and where human cases of the disease were reported (personal communication). The Jardim União neighborhood is located next to a forest region; however, this variable was not considered as a risk factor for CVL in this study. In addition, the occurrence of the disease in men was statistically associated with cases where the dogs remained inside the home (GAVGANI et al., 2002; BORGES et al., 2009) and the presence of livestock in the property; such relation was not found here, though. In contrast, the presence of agriculture crops around the household was associated to canine leishmaniasis infection with a 1.68 risk of disease occurrence. This characteristic can stimulate the establishment of sand flies in these environments (MARZOCHI; MARZOCHI, 1994).

Although cases of human and canine VL were previously reported in this area (MESTRE et al., 2011), the knowledge about these cases by the owners interviewed did not indicate a protection factor, on the contrary, it doubled the chances of their dogs acquire the infection. The lack of garbage collection represented a risk factor (OR 4.53) for the occurrence of dog infection in the Barreiro Branco neighborhood when compared to Coxipó do Ouro, where such service is provided. As observed by Moreno et al. (2005), the lack of public garbage collection tends to predispose the occurrence of infection by contributing to the proliferation of the L. longipalpis. 
Although CVL autochthony is known in Cuiabá (ALMEIDA et al., 2010, 2011), the maintenance of high levels of seropositive dogs in areas with occurrences of the disease reinforces the importance of epidemiological surveillance, as well as the knowledge of the risk factors associated to the canine infection, as a way to clarify the gaps that may be involved in the maintenance of the transmission cycle. In this study, despite the fact that the inhabitants know about the leishmaniasis control, no measure has been adopted by the government. This study contributes to the knowledge on the aspects of canine visceral leishmaniasis in Cuiabá and indicates the need to start educational and sanitary programs in this city.

\section{Acknowledgements}

The authors are grateful to the 'BioManguinhos' Institute - FIOCRUZ, Rio de Janeiro, Brazil, for providing the indirect immunofluorescence kits used in this research. This work was supported, in part, by grants from the 'Fundação de Amparo a Pesquisa do Estado de Mato Grosso' and 'Conselho Nacional de Desenvolvimento Cientifico e Tecnologico' - CNPq (process no 474894/2010-0).

\section{References}

Almeida ABPF, Faria RP, Pimentel MFA, Dahroug MAA, Turbino NCMR, Sousa VRF. Inquérito soroepidemiológico de leishmaniose canina em áreas endêmicas de Cuiabá, Estado de Mato Grosso. Rev Soc Bras Med Trop 2009; 42(2): 156-159. http://dx.doi.org/10.1590/ S0037-86822009000200012

Almeida ABPF, Mendonça AJ, Sousa VRF. Prevalência e epidemiologia da leishmaniose visceral em cães e humanos, na cidade de Cuiabá, Mato Grosso, Brasil. Cienc Rural 2010; 40(7): 1610-1615. http://dx.doi. org/10.1590/S0103-84782010005000102

Almeida ABPF, Sousa VRF, Boa-Sorte EC, Figueiredo FB, Paula DAJ, Pimentel MFA, et al. Use of parasitological culture to detect Leishmania (Leishmania) chagasi in naturally infected dogs. Vector Borne Zoonotic Dis 2011; 11(12): 1555-1560. PMid:21919725. http://dx.doi. org/10.1089/vbz.2011.0723

Amora SSA, Santos MJP, Alves ND, Costa SCG, Calabrese KS, Monteiro $\mathrm{AJ}$, et al. Fatores relacionados com a positividade de cães para leishmaniose visceral em área endêmica do Estado do Rio Grande do Norte, Brasil. Cienc Rural 2006; 36(6): 1854-1859. http://dx.doi.org/10.1590/ S0103-84782006000600029

Antonialli SAC, Torres TG, Paranhos Filho AC, Tolezano JE. Spatial analysis of American Visceral Leishmaniasis in Mato Grosso do Sul State, Central Brazil. J Infect 2007; 54(5):509-514. PMid:16979241. http:// dx.doi.org/10.1016/j.jinf.2006.08.004

Arias JR, Monteiro PS, Zicker F. The reemergence of visceral leishmaniasis in Brazil. Emerg Infect Dis 1996; 2(2): 145-146. PMid:8903218 PMCid:2639817. http://dx.doi.org/10.3201/eid0202.960213

Baruffa G, Cury P. Contribuição ao estudo do calazar em Mato Grosso. Rev Patol Trop 1973; 2(1): 345-361.

Borges BKA, Silva JA, Haddad JPA, Moreira EC, Magalhães DF, Ribeiro LML, et al. Presença de animais associada ao risco de transmissáo da leishmaniose visceral em humanos em Belo Horizonte, Minas Gerais. Arq Bras Med Vet Zootec 2009; 61(5): 1035-1043. http://dx.doi.org/10.1590/ S0102-09352009000500004

Brasil. Ministério da Saúde. Manual de Vigilância e Controle da Leishmaniose Visceral. Brasília: Ministério da Saúde; 2006. 122 p.

Brasil. Ministério da Saúde. Casos confirmados de Leishmaniose Visceral, Brasil, Grandes Regióes e Unidades Federadas: 1990 a 2010. Brasília: Ministério da Saúde; 2011. [cited 2011 Sept 17]. Available from: http:// portal.saude.gov.br/portal/arquivos/pdf/lv_casos_05_09_11.pdf.

Cruz I, Acosta L, Gutiérrez MN, Nieto J, Cañavate C, Deschutter $\mathrm{J}$, et al. A canine leishmaniasis pilot survey in an emerging focus of visceral leishmaniasis: Posadas (Misiones, Argentina). BMC Infect Dis 2010; 10(342): 1-7.

Dantas-Torres F, Brito MEF, Brandão-Filho SP. Seroepidemiological survey on canine leishmaniasis among dogs from an urban area of Brazil. Vet Parasitol 2006; 140(1-2): 54-60. PMid:16621286. http://dx.doi. org/10.1016/j.vetpar.2006.03.008

Dantas-Torres F. Canine leishmaniosis in South America. Parasit Vector 2009; 2(S1): 1-8. PMid:19426440 PMCid:2679393. http:// dx.doi.org/10.1186/1756-3305-2-S1-S1

De Paula CC, Figueiredo FB, Menezes RC, Mouta-Confort E, Bogio A, Madeira MF. Canine visceral leishmaniasis in Maricá, State of Rio de Janeiro: first report of an autochthonous case. Rev Soc Bras Med Trop 2009; 42(1): 77-78. PMid:19287941.

Frehse MS, Greca Júnior H, Ullmann LS, Camossi LG, Machado JG, Langoni H, et al. Surveillance of canine visceral leishmaniasis in a disease-free area. Rev Bras Parasitol Vet 2010; 19(1): 62-64. PMid:20385062. http://dx.doi.org/10.4322/rbpv.01901011

Gavgani ASM, Mohite H, Edrissian GH, Mohebali M, Davies CR. Domestic dog ownership in Iran is a risk factor for human infection with Leishmania Infantum. Am J Trop Med Hyg 2002; 67(5): 511-515. PMid:12479553.

Harhay MO, Olliaro PL, Costa DL, Costa CHN. Urban parasitology: visceral leishmaniasis in Brazil. Trends Parasitol 2011; 27(9): 403-409. PMid:21596622. http://dx.doi.org/10.1016/j.pt.2011.04.001

Instituto Brasileiro de Geografia e Estatística - IBGE. População da cidade de Cuiabá em 2010. Rio de Janeiro: IBGE; 2011. [cited 2011 Sept 12]. Available from: http://www.ibge.gov.br/cidadesat/topwindow.htm?1.

Lucey C, Weina PJ. Applying the STARD (Standards for Reporting of Diagnostic Accuracy) checklist to the 2007 Transfusion article 'Evaluation of a new enzyme-linked immunosorbent assay for detection of Chagas antibody in US blood donors'. Trans $R$ Soc Trop Med Hyg 2008; 102(2): 155-160. PMid:18082863. http://dx.doi. org/10.1016/j.trstmh.2007.10.016

Mancianti F, Gramiccia M, Gradoni L, Pieri S. Studies on canine leishmaniasis control. I. Evolution of infection of different clinical forms of canine leishmaniasis following antimonial treatment. Trans R Soc Trop Med Hyg 1988; 82(4): 566-567. http://dx.doi. org/10.1016/0035-9203(88)90510-X

Marzochi MCA, Marzochi, KBF. Tegumentary and Visceral Leishmaniases in Brazil - Emerging Anthropozoonosis and Possibilities for Their Control. Cad Saúde Públ 1994; 10(S2): 359-375. PMid:15042226. http://dx.doi.org/10.1590/S0102-311X1994000800014

Marzochi MCA, Fagundes A, Andrade MV, Souza MB, Madeira MF, Mouta-Confort E, et al. Visceral leishmaniasis in Rio de Janeiro, Brazil: eco-epidemiological aspects and control. Rev Soc Bras Med 
Trop 2009; 42(5): 570-580. PMid:19967242. http://dx.doi.org/10.1590/ S0037-86822009000500017

Mestre GLC, Fontes CJF. A expansão da epidemia de leishmaniose visceral no Estado de Mato Grosso, 1998-2005. Rev Soc Bras Med Trop 2007; 40(1): 42-48. PMid:17486252. http://dx.doi.org/10.1590/ S0037-86822007000100008

Mestre GLC, Ribeiro ALM, Miyazaki RD, Rodrigues JSV, Almeida ABPF, Sousa VRF, et al. Phlebotomine sand flies and canine infection in areas of human visceral leishmaniasis, Cuiabá, Mato Grosso. Rev Bras Parasitol Vet 2011; 20(3): 228-234. PMid:21961754. http://dx.doi. org/10.1590/S1984-29612011000300010

Missawa NA, Borba JF. Leishmaniose visceral no município de Várzea Grande, estado de Mato Grosso, no período de 1998 a 2007. Rev Soc Bras Med Trop 2009; 42(5): 496-502. PMid:19967230. http://dx.doi. org/10.1590/S0037-86822009000500005

Moreno EC, Melo MN, Genaro O, Lambertucci JR, Serufo JC, Andrade ASR, et al. Risk factors for Leishmania chagasi infection in an urban area of Minas Gerais State. Rev Soc Bras Med Trop 2005; 38(6): 456-463. PMid:16410918. http://dx.doi.org/10.1590/ S0037-86822005000600002

Murray HW, Berman JD, Davies CR, Saravia NG. Advances in leishmaniasis. Lancet 2005; 366(9496): 1561-1577. http://dx.doi. org/10.1016/S0140-6736(05)67629-5

Nascimento ELT, Martins DR, Monteiro GR, Barbosa JD, Ximenes MFFM, Maciel BL, et al. Forum: geographic spread and urbanization of visceral leishmaniasis in Brazil. Postscript: new challenges in the epidemiology of Leishmania chagasi infection. Cad Saude Públ 2008; 24(12): 2964-2967. PMid:19082290. http://dx.doi. org/10.1590/S0102-311X2008001200028
Oliveira LCP, Araújo RR, Alves CR, Mouta-Confort E, López JA, Mendonça-Lima FW. Seroprevalence and risk factors for canine visceral leishmaniasis in the endemic area of Dias D'Ávila, State of Bahia, Brazil. Rev Soc Bras Med Trop 2010; 43(4): 400-404. PMid:20802939. http:// dx.doi.org/10.1590/S0037-86822010000400013

Ranjan A, Sur D, Singh VP, Siddique NA, Manna B, Lal CS, et al. Risk factors for Indian Kala-Azar. Am J Trop Med Hyg 2005; 73(1): 74-78. PMid:16014837.

Rondon FCM, Bevilaqua CML, Franke CR, Barros RS, Oliveira FR, Alcântara AC, et al. Cross-sectional serological study of canine Leishmania infection in Fortaleza, Ceará state, Brazil. Vet Parasitol 2008; 155(1-2): 24-31. PMid:18565676. http://dx.doi. org/10.1016/j.vetpar.2008.04.014

Santos JML, Dantas-Torres F, Mattos MRF, Lino FRL, Andrade LSS, Souza RCA, et al. Prevalência de anticorpos antileishmania spp em cães de Garanhuns, Agreste de Pernambuco. Rev Soc Bras Med Trop 2010; 43(1): 41-45. PMid:20305967. http://dx.doi.org/10.1590/ S0037-86822010000100010

Silva MR, Marques MJ, Romanha AJ, Santa-Rosa ICA, Carneiro $\mathrm{CM}$, Reis AB. Autochthonous canine visceral leishmaniasis in a non-endemic area: Bom Sucesso, Minas Gerais State, Brazil. Cad Saúde Públ2008; 24(2): 281-286. PMid:18278274. http://dx.doi.org/10.1590/ S0102-311X2008000200006

Souza GD, Santos E, Andrade Filho JD. The first report of the main vector of visceral leishmaniasis in America, Lutzomyia longipalpis (Lutz \& Neiva) (Diptera: Psychodidae: Phlebotominae), in the state of Rio Grande do Sul, Brazil. Mem Inst Oswaldo Cruz2009; 104(8): 1181-1182. PMid:20140381. http://dx.doi.org/10.1590/S0074-02762009000800017

World Health Organization - WHO. Leishmaniasis. WHO; 2008. [cited 2010 May 28]. Available from: www.who.int. 